\title{
Stakeholder Management: An Insightful Overview of Issues
}

\author{
Ayman Mashali \\ ayman.mashali@yahoo.com, amashali@km.qa \\ Faculty of Engineering, Mansoura University, Mansoura, Egypt / KAHRAMAA, Doha, Qatar
}

Emad Elbeltagi

eelbelta@mans.edu.eg

Faculty of Engineering, Mansoura University, Mansoura, Egypt

Ibrahim Motawa

i_a_motawa@hotmail.commans.edu.eg

Faculty of Engineering, Mansoura University, Mansoura, Egypt

Mohamed Elshikh

i a motawa@hotmail.commans.edu.eg

Faculty of Engineering, Mansoura University, Mansoura, Egypt

\begin{abstract}
This paper attempts to contribute towards investigating the existing literature base of stakeholder management (SM), provide a compilation, and define any gaps in this area. Besides, explore different groups of critical success factors (CSFs) and grouping these actors. This study is based on reviewing the literature. Therefore, more than a hundred research papers were searched by the key terms specified in a preceding literature review. Succeeding tours of abstract research surveys resulted in forty-two research papers being picked for the compilation. SM constructs were identified, and the following crucial analysis defined the literature base gaps. The most notable outcomes are the absence of research that has studied BIM-based stakeholder management, especially in mega projects. Additionally, further investigations are still required to study the SM influence throughout the different stages of the project life cycle and study the impact of project type and contract type in SM. However, there is still considerable debate about the SM nature and merits approach. This study presents a comprehensive gathering of all earlier identified SM processes through a structured approach. Additionally, a more realistic and practical methodology for the development and implementation of SM will emerge, and twenty-seven CSFs associated with SM in construction projects are identified. The study is expected to have a theoretical contribution to this subject, especially in the context of the Qatari construction industry.
\end{abstract}

Keywords: Construction industry; Implementation; Stakeholder engagement; Management; Stakeholder management; Critical success factors (CSFs)

\section{INTRODUCTION}

The construction industry is highly complicated that requires strict systems to achieve projects efficiently and on time. In trying to maintain competitiveness, there has been a growing necessity in institutions to link the information supplied by every section into a joint entity. The outcome, there was widened research and study concentrating on the execution process and its CSFs (Al-Mashari et al., 2003; Hong \& Kim, 2002; Xu et al., 
2002; Ribbers \& Schoo, 2002). Nevertheless, it seems that much of the literature has concentrated on SM with too limited concern to stakeholders' perspectives. Concerning a project execution crew, a deeper understanding of SM would make it likely to evaluate the project planning stage and determine if the interests are being managed as efficiently as potential. Finally, this will reinforce the likelihood of gaining more significant success levels and, thus, cost-savings, time-saving, efficiency, and quality in their project. Moreover, different aspects of implementation influence some stakeholder sets more than others, and some sets are higher qualified to remark on particular side than others. Furthermore, the identified gaps of the SM approach, identified by previous researchers, need to be further investigated in terms of how they have been addressed in the SM literature. Based on the outcomes of a full gathering and analysis of SM, this study seeks to introduce a new protocol to other research on SM prosses and to uncover the more in-depth application of the broad aspects of SM.

\section{STAKEHOLDER MANAGEMENT AND CSFS LITERATURE COMPILATION}

As per reviewing the literature for SM and identifying its success factors, the first step was to categorize and group success factors that, fully initially, seemed to indicate a similar phenomenon. Then, a consecutive round of the analysis of the concepts resulted in producing $31 \mathrm{CSFs}$ in total.

\subsection{STAKEHOLDERS' DEFINITION AND CATEGORIES Stakeholder Definitions}

PMBOK (2018) defines a stakeholder as an individual, groups, or organizations that may affect, be affected through, or perceive themselves to be affected by a decision, activity, or outcome of a project. The stakeholder literature presented different conceptual and definitions of stakeholders ranging from wide to narrow views. Freeman (1984) proposed a classic definition of stakeholders that it is any group and individuals who can affect or is affected through the fulfilment of an organization's objective. However, this definition is wide in the meaning that it does not specify the relationship between stakeholders and the firm. Also, it does not take a situation whether the claims of the stakeholders are legitimate or not. In conclusion, the most common definitions of project stakeholders broadly, as any individual or organization who can affect or be affected through the project.

\section{Stakeholders Categories}

PMBOK (2018), categorized stakeholders into two categories as (i) Internal project stakeholders generally include the project sponsor, project team, support staff, and internal customers for the project. Other internal stakeholders include top management, other functional managers, and other project managers because organizations have limited resources. (ii) External project stakeholders include the project's customers (if they are external to the organization), competitors, suppliers, and other external groups that are potentially involved in the project or affected by it, such as government officials and concerned citizens. Other categorizations in the literature are based on stakeholders' involvement in the project and the character of their relationship with the project, the nature of stakeholders' claim and their attitude towards the project, their role in the 
project, and their degree of anticipating behavior (Aaltonen, 2010; Cova et al., 2002 and Moodley et al., 2008).

The primary stakeholder groups are those who are considered as a base to the presence of the organization, and often most of them have some formal contract with the organization as owners, employees, customers, and suppliers. Secondary stakeholders are the group that plays an essential part in giving credibility and acceptance to the organization for its activities and include, communities, governments, and competition (Ayuso et al., 2006; Podnar et al., 2006). Wheeler and Sillanpaa (1997) classified stakeholders into two additional dimensions of social and non-social. Stakeholders are commonly classified by a broad range of attributes, such as interest, attitude, impact, influence, power, urgency, risk, and satisfaction (Mitchell et al., 1997; McElroy \& Mills, 2003). Miller et al. (2001) stated that successful projects display exceptional SM and maybe follow the process of stakeholder identification, classification, analysis, and management strategy formularization.

\subsection{CRITICAL SUCCESS FACTORS (CSFs) COMPILATION}

Numerous researchers have applied the CSFs as a method to enhance the realization of the management process (Yang et al., 2009b; Yu, 2007; Jefferies, 2002). CSFs can be defined as "areas, where outcomes if they are satisfying, will ensure strong competitive achievement for the organization" (Yang et al., 2009a). CSFs are identified from studies on SM, in general, or "the works of those who have discussed a special factor in detail" (Wong \& Aspinwall, 2005). Based on an extensive literature review, six groups, comprising 31 factors contributing to the success of SM were identified and proposed as follows:

\section{Group 1: Project Type}

Project characteristics are significant to project success (Songer \& Molenaar, 1997).

- Industrial: Industrial projects are characterized by a high level of complexity (Anderson et al. 2016). While numerous researches evaluate project complexity, little integrated studies present a proper approach for successfully managing the project complexity (Liu et al., 2017). Therefore, there is a significant need for an applicable approach that can simplify the assessment process to manage the project effectively.

- Infrastructure

- Buildings: The construction of buildings suffers from the isolation of construction responsibility from the design phase. Grilo et al., (2007) supported these issues and mentioned that the cause is the contractors' relegation from the design process.

\section{Group 2: Contract type.}

The organization must have a comprehensive construction contract, and the contract must realize an efficient collaborative environment with a balance between vendor and client.

- $\quad$ Lump Sum

- Measurement

- Cost Reimbursable 
- Design-Build (EPC): Design-build (D-B) is an undertaking procurement process where one entity or consortium is contractually liable for the construction and design (Songer et al., 1997). D-B is illustrated to be an efficient delivery technique and has become common within the world in the current days (Xia \& Chan, 2010). In D-B projects, the pre-qualification of implied tenders is essential for gaining a first evaluation of engaged individuals' fitness for undertaking the project (Lam et al., 2004). Furthermore, conditions, regulations, and laws of settlement and contract documentation must be complete regarding parties' rights and duties to give sufficient information toward the responsibilities at many phases of construction and design (Nguyen et al., 2004).

\section{Group 3: Decision making.}

Whereas not broadly cited, this group deserves specific consideration. Moreover, this concept indicates the need for the team to be enabled to make crucial decisions in proper time, to allow effective timing for the implementation (Shanks \& Parr, 2000; Chen, 2001; Gupta, 2000).

- Transparent Evaluation of the alternative solution based on stakeholder concern: A clear asses of alternate solutions for the improvement of a construction industry based on the concerns of stakeholders would assist the managers to build the foundation of confidence required for a satisfactory SM process (Olander \& Landin, 2008).

- Ensuring effective communication among the project's stakeholder: The success of a project is connected by efficiently communicate and manage relationships among the different project stakeholders. Therefore, to ensure the project's success, much information needs to be communicated on a steady basis to all major stakeholders, including expectations, goals, and needs. In contrast, communications comprise the processes needed to secure the appropriate and proper generation, collection, distribution, storage, and recovery of all data of the project. Furthermore, efficient communication builds a bridge among different project stakeholders, linking many cultural and organizational backgrounds, various expertise levels, and many views and interests in the project fulfilling (Jergeas et al., 2000; Čulo \& Skendrović, 2010).

- Formulate appreciate strategy to deal with stakeholder: The strategy of SM is the behavior of wherewith the project directors addresses various stakeholders needs (Karlsen, 2002). Thus, many researchers repeated the urgency to address the implementation strategy by a gradual approach (Cliffe, 1999; Gupta, 2000; Scott \& Vessey, 2000; Motwani et al., 2002; Robey et al., 2002; Mandal \& Gunasekaran, 2003).

- Additionally, 'Stakeholders' reactions to the strategies' is a vital factor when project managers make decisions regarding the strategies to deal with stakeholders (Freeman et al., 2007). Therefore, the project team must predict stakeholders' behavior in fulfilling strategy (Cleland \& Ireland, 2007), where an effective strategy for project management is that ensures the success of the project (Smith \& Wilkins, 1996). Besides, it was determined and described five different types, ranging from negative to active approaches used by the construction industry companies. SM strategies are: compromising, adaptation, avoidance, influence and dismissal (Hammad, 2013). 


\section{Group 4: The best manages stakeholder team.}

The challenges of stakeholder perspectives of unreasonable and wrongly concentrated about a project and its expected outcomes may lead to problems in project implementation (Olander, 2007; Jha \& Iyer, 2006). Most of project stakeholders' research on managerial behavior focused on the conceptual development of various managerial frameworks, tools, and processes to identify, categorize and manage project stakeholders and studying the role and value of SM process (Bourne \& Walker, 2005; Cleland, 1986; Cleland, 1995; Cleland, 1998; Olander \& Landin, 2005).

- Client Team: There is a necessity for communication, session and consultation with numerous essential stakeholders, though, especially with the Owner (Al-Mudimigh et al., 2001; Al-Mashari et al., 2003). Organizations necessitate keeping their owners informed of their projects to keep away errors (Holland \& Light, 1999; Al-Mudimigh et al., 2001; Mandal \& Gunasekaran, 2003).

- Formulate Project Management Team: It has declared in the course of the literature that there is a significant want to build a strong and powerful staff that comprises the organization's satisfactory and brightest employees. These employees must own established credit (Cliffe, 1999), and there have to be a pledge to release the employees to the implemented mission on a full-time basis (Siriginidi, 2000b; Shanks \& Parr, 2000). The team needs to hold the necessary skills to investigate details when conducting the planning phase (Soh et al., 2000). Once the team has been set up, it would then be primary to teach and train the employees (Bajwa et al., 2004).

- Supervision Consultant Team: Several researchers have supported the necessity to add a consultant as part of the execution crew (Trimmer et al., 2002; Motwani et al., 2002; Bajwa et al., 2004; Kalling, 2003). Still, as part of this link, it is essential to manage the transfer of knowledge from the consultant to the firm (Al-Mashari et al., 2003; Skok \& Legge, 2002).

- External Party team: It is remarked that if a construction authority does not be in complex mega-projects, a third-party will hold the position of the construction authority or a project management firm expert in similar projects type (Adrem et al., 2006). This concept is observed in several airport projects, such as the Doha Airport Expansion project where construction authority control is needed to obtain a balance between stakeholder's interests.

- Contractor Team: Designers could gain from the early contractors' engagement who usually aren't engaged in the tender stage previously in design management systems and traditional procurement (Pocock et al., 1997). Subsequently, the contractor's involvement at the design stage owns an essential influence on the ought right-firsttime design and will have a favorable influence on efficiency, quality, constructability, and speed construction of the project (Cooper et al., 2005). Also, while contractors come to be involved, they have minimal options since most designs are previously determined (Adrem et al., 2006).

\section{Group 5: Stakeholders' Categories in the Project stages}

Most of the researchers investigating SM have mentioned the vital significance of 
identifying stakeholders (Karlsen, 2002; Olander, 2006; Walker et al., 2008; Jepsen \& Eskerod, 2009). Although the project stakeholders can be divided into many types according to various criteria, the question of "who are the stakeholders?" must be answered earlier (Pinto et al., 2009). Project stakeholders influence the project management procedure (Olander, 2007). Therefore, realizing the stakeholders' impact is significant for planning and implementing enough strict SM processes (Olander \& Landin, 2005). Accordingly, if an external SM process conducted properly, it represents an opportunity for project improvement (Oalnder, 2006).

- Initiation stage: Numerous researchers indicated that project performance, in terms of time, schedule, scope, quality, and safety, will be enhanced by implementing SM at the early project stages (Chen et al., 2001). Moreover, the project management team should classify project stakeholders in the early project stages to ensure the project success. It is crucial to identify the project stakeholders and to get the stakeholders' engagement process for integrating them into the design and construction activates and to determine the interference among them and the SM problems to improve it (Weshah et al., 2014a). Clear and appropriate stakeholder definition is considered as one of the essential frequent contributors to project success, and it is a product of the initiation phase of project development. Therefore, success throughout the next phases would be highly dependent on the level of the effort spent during this phase. A specific mega-project execution approach is selected at this vital stage in a project's life span (Gabriel, 2015).

- Planning stage: The project activities could be secured in an excellent situation by efficient overall management actions in leading, planning, controlling, and organizing (Nguyen et al., 2004; Mandal \& Gunasekaran, 2003). The method of planning should be thoughtful of tasks to be fulfilled (Mandal \& Gunasekaran, 2003), and subsequently, the planning should include external and internal best practices for execution (Al-Mudimigh et al., 2001). In mega-projects, there is a sequence of phases through which a project develops to its conclusion. In each succeeding phase of a project, new and different activities are developed, with the outcome of one phase becoming an input to the next phase. Different studies have shown that greater efforts in project planning and SM lead to improved project performance (Gabriel, 2015). This stage develops the design in a logical array endeavoring to gain approval on progressing to the execution stage. It is usually improved subsequent signing the project funding and delivering a suitable design solution that fits the client's requirements (Wahab, 2011). The planning stage aims to ensure complete commercial power to move to the execution phase and following achieving the owner is knowledgeable of the works' range, and likely risks can be known (Cooper et al., 2005).

- Execution stage: During the execution phase, almost all SM areas have to be considered. This phase consists of two stages: (1) project construction and (2) Monitor and Control on-site. The project team must be familiar with the environmental conditions, local weather, and the geotechnical conditions have to be checked and studied carefully (Cooper et al., 2005; Weshah, et al., 2014a). During this stage, the organization generates alternatives and chooses the preferred alternative. The significance of scope definition and data reliability is higher than in the previous 
phase. Also, the project manager and crucial project resources are assigned at this stage (Hussain, 2015). Also, information, data, and feedback are regularly gathered and made available to concerned stakeholders on time (Gabriel, 2015).

- Monitoring and Controlling stage: Through this stage, the project has been completely funded, a detailed schedule is in place, and the executive team engagement is high for executing the project according to the project schedule and budget. Where the performance of the project team is measured through the project execution phase adds progress and performance reports go to the client's side, executives, and all project stakeholders (Hussain, 2015). Also, throughout the monitor and controlling process, performance information is gathered, analyzed, and distributed in periodical reports (Gabriel, 2015).

- Closing stage: The closing stage includes the owner's operations teams; all the project teams and contractors are released from the project (Hussain, 2015). However, the project handing over is a long process, and especially when there are complicated activities. So, this stage ensures a soft process handing-over. Therefore, as-built designs are documented and handed over to the client representative, whereas preparation workshop will carry out to ensure that the end-users' teams are qualified for operation and maintenance works (Hussain, 2015).

- Maintenance stage: The object of this stage is to reveal the maintenance requirements of the completed project. Where it is very significant to the engagement of the facility management in initial design phases, which will secure the maintenance stage limited uncertain. Also, documenting the project's legacy archive duly will succeed in reducing the necessity for surveys of the completed property (Cooper et al., 2005).

\section{Group 6: Management support.}

Top management support is crucial for effective SM (Yang et al., 2009b). Therefore, for guaranteeing successful SM, individuals should be ready to participate in power and resource that would help the overall organization's aim (Brooke \& Litwing, 1997). Moreover, the commitment and support of senior management were one of the most widely mentioned CSFs. Also, this concept indicated the need to have obliged leadership at the senior management level. Besides, it is referred to the necessity for management to expect any weakness that might be faced (Motwani et al., 2002) and the requirement for top management who would be involved in the strategic planning, but who are likewise technically orientated (Yusuf et al., 2004). Reliable and committed leadership at the top management level is essential to the success of project achievement (Sarker \& Lee, 2003).

- Managing Stakeholders with corporate responsibilities: Project management indicates the continuous management of the execution plan. Accordingly, it includes not only the planning phases but also the distribution of duties to many members, the definition of critical paths, milestones, training, and planning of human resources, and lastly, the judgment of success measures (Nah et al., 2001). Additionally, there is a necessity to institute a steering panel included top management of various corporate duties, top project management reps, and end-users (Somers \& Nelson, 2001, 2004).

- Flexible project organization: Flexible project organization is necessitated to 
overcome the complicated and doubts of execution (Li et al., 2011), which is confirmed by Olander and Landin (2008), who come to the influence of the flexibility performance of the project to hire employees to realize the aims of the project. As one purpose of SM is to obtain agreement from stakeholders on the project execution, and this will be accomplished if a company is established to include enough resources for communication and interaction with stakeholders.

- Project manager Competence / Skills: The project managers should own high and strong leadership skills, technical, business, and managerial competencies (Mandal \& Gunasekaran, 2003; Kraemmergaard \& Rose, 2002). In most conditions, stakeholders' relationship is managed by projects' managers; therefore, the outcomes of SM are subject to the PMs' relationships, experience, capability, and power (Karlson, 2002). Also, PMs should be skillful communicators and negotiators to be fitted with directing different stakeholder expectations and building a positive culture exchange inside the overall company (Olander \& Landin, 2008). Therefore, the PMs role should comprise not only easily a knowledge of the technical certainties at hand but also of the connections among the environment, technology, community, and people in it. Moreover, The PMs should gain knowledge about the project place and engage the local society when planning of the construction project.

\section{RESEARCH METHODOLOGY}

The full literature review has included copious note-taking that has highlighted all likely sources to SM, through adopting a conceptual analysis approach. CSF can be described as; a reference to any element or stipulation that was considered essential for the stakeholder management successfully implementation. The papers comprising a CSFs' reference of SM implementations were investigated and analyzed to code the specified constructs. Consequently, all CSFs, regardless of the characterize, were noted that the sorting stage would begin to place CSFs in the same categories. Since the purpose of this paper was to obtain a deep understanding of SM issues and different CSFs that previously identified by other researchers. Therefore, a content analysis was a suitable analysis methodology. It is the utmost common method for analyzing texts (Silverman, 2000).

\section{ANALYSIS OF SM LITERATURE}

The researchers have much usually concentrated on only a particular perspective of the implementation process or a particular SM. Thus, there is limited study documented that includes all essential SM states. Despite methodology, all the previous studies mentioned above have been narrowly concentrated, providing to the readers a constricted yet comprehensive view of a particular success factor. The comparatively weak degree of stakeholder consultation and the shortage of reporting of their personal views, as evidenced in the previous citations, is a vital gap in the existing literature base, and it illustrates the prime shortage of the CSF approach. Besides, there is too small offered in the literature that endeavors to identify or describe the particular tactics needed to manage and fulfil these SM activities successfully. As expressed by the references mentions above, the views on SM and precisely what SM includes vary hugely. These required to be more investigated, thus that these ideas can be better displayed in a way 
that makes it achievable for the project manager to execute and control effectively. Moreover, though there is no doubt that SM is a crucial regard, it is not clear exactly how it could be handled.

Table 1: Title of CSFs in literature

\begin{tabular}{|c|c|c|c|c|}
\hline CSFs & CSF category & $\begin{array}{l}\text { Group } \\
\text { No }\end{array}$ & \multicolumn{2}{|c|}{ Group description } \\
\hline $\mathrm{C} 1$ & Industrial Project & 1 & \multirow{4}{*}{\multicolumn{2}{|c|}{ Project Type }} \\
\hline $\mathrm{C} 2$ & Infrastructure Project & 1 & & \\
\hline $\mathrm{C} 3$ & Buildings Project & 1 & & \\
\hline $\mathrm{C} 4$ & \begin{tabular}{|l|} 
Others Project \\
\end{tabular} & 1 & & \\
\hline $\mathrm{C} 5$ & Lump Sum & 2 & \multirow{4}{*}{\multicolumn{2}{|c|}{ Contract Type }} \\
\hline C6 & Measurement & 2 & & \\
\hline $\mathrm{C} 7$ & Cost Reimbursable & 2 & & \\
\hline $\mathrm{C} 8$ & Design-Build (EPC) Project & 2 & & \\
\hline C9 & $\begin{array}{l}\text { Transparent Evaluation of the alternative solution } \\
\text { based on stakeholder concern. }\end{array}$ & 3 & \multirow{3}{*}{\multicolumn{2}{|c|}{ Decision making }} \\
\hline $\mathrm{C} 10$ & $\begin{array}{l}\text { Ensuring effective communication among the project's } \\
\text { stakeholder. }\end{array}$ & 3 & & \\
\hline $\mathrm{C} 11$ & Formulate appreciate strategy to deal with stakeholder. & 3 & & \\
\hline $\mathrm{C} 12$ & Client Team & 4 & \multirow{5}{*}{\multicolumn{2}{|c|}{$\begin{array}{l}\text { The best manages } \\
\text { stakeholder team }\end{array}$}} \\
\hline $\mathrm{C} 13$ & "Project Management team" P.M Team & 4 & & \\
\hline $\mathrm{C} 14$ & S.C Team & 4 & & \\
\hline $\mathrm{C} 15$ & Ex. $3^{\text {rd }}$ Party team & 4 & & \\
\hline $\mathrm{C} 16$ & Contractor Team & 4 & & \\
\hline $\mathrm{C} 17$ & Initiation stage for; a- Internal stakeholder & 5 & \multirow{6}{*}{$\begin{array}{l}\text { 4a- Internal } \\
\text { stakeholder }\end{array}$} & \multirow{12}{*}{$\begin{array}{l}\text { Stakeholders' } \\
\text { Categories in } \\
\text { the Project } \\
\text { stages }\end{array}$} \\
\hline C18 & Planning stage for; a- Internal stakeholder & 5 & & \\
\hline C19 & Execution stage for; a- Internal stakeholder & 5 & & \\
\hline $\mathrm{C} 20$ & Monitoring \& Controlling for; a- Internal stakeholder & 5 & & \\
\hline $\mathrm{C} 21$ & Closing stage for; a- Internal stakeholder & 5 & & \\
\hline $\mathrm{C} 22$ & Maintenance stage for; a-Internal stakeholder & 5 & & \\
\hline $\mathrm{C} 23$ & Initiation stage for; b- External stakeholder & 5 & \multirow{6}{*}{$\begin{array}{l}\text { 4b-External } \\
\text { stakeholder }\end{array}$} & \\
\hline $\mathrm{C} 24$ & Planning stage for; b- External stakeholder & 5 & & \\
\hline $\mathrm{C} 25$ & Execution stage for; b- External stakeholder & 5 & & \\
\hline $\mathrm{C} 26$ & Monitoring \& Controlling for; b- External stakeholder & 5 & & \\
\hline $\mathrm{C} 27$ & Closing stage for; b- External stakeholder & 5 & & \\
\hline $\mathrm{C} 28$ & Maintenance stage for; b- External stakeholder & 5 & & \\
\hline $\mathrm{C} 29$ & Managing Stakeholders with corporate responsibilities & 6 & \multirow{3}{*}{\multicolumn{2}{|c|}{ Management support }} \\
\hline $\mathrm{C} 30$ & Flexible project organization & 6 & & \\
\hline C31 & Project manager Competence / Skills & 6 & & \\
\hline
\end{tabular}

Based on the extensive literature review of SM, 31 critical success factors are identified in construction projects, and these factors were collected and classified into six groups, as presented in Table 1. Such compilation is based on the range of CSFs/ SM citations. Nevertheless, there was further analysis carried that attempted to expose any apparent gaps in the literature to time. As an outcome, the characteristic apparent from this discussion is the very shortage of in-depth coverage of CSFs. Moreover, added important note was the absence of BIM based-SM cited in the literature. Lastly, the notion of management support, one of the common broadly cited CSFs, and the range of activities comprised of management support are varied. 
This paper would help interested professionals to have more information about the potential and the most critical success factors for SM. Where, this information may minimize conflict among different project stakeholders involved in construction projects, which may positively impact project performance. As mentioned above, and based on the review of the literature, the importance for more study about SM and considerations of the possible positive influence of SM in MCPs are highlighted. Also, the perspective on SM that identifies, examines and evaluates this issue is missing in the literature. In order to bridge this gap, this research concentrates on exploring and evaluating SM as the primary step for achieving better outputs.

Nevertheless, further investigations are still needed to improve SM during the different stages of project execution. Also, it is necessary to evaluate and analyze SM and their impact, for managing the stakeholder in MCPs, and the effect of internal and external stakeholders in the construction industry. Furthermore, translating the theoretical findings into an empirical study and show the impact of using the SM on the overall cost and productivity of a project.

\section{CONCLUSION}

Research on SM implementation and CSFs is a valuable step toward enhancing the chances of project success. A review of the SM and CSFs/implementation shows that, in numerous cases, CSFs are introduced based on a review of limited case studies or the previously published literature. As an outcome, one fundamental limitation of this paper is the occurrence of duplicates in the frequency analysis of the CSFs. Moreover, in cases when past researchers have sought to identify CSFs by their empirical study, they have so often concentrated on only a particular perspective of the implementation or a particular type of CSFs. Whereas, preceding methodology in investigating CSFs have been very alike in the method to the fragmented methodology. Also, it has been exposed that there was no study carried to date that has reflected the significance of CSFs during SM implementation by adopting BIM. That is a significant finding. While management support emerges being one of the common widely cited CSFs, there yet seems to be considerable variance for what exactly is surrounded. Because of the literature limitations mentioned above and according to the suggestions from different studies, there is a necessity to concentrate further research efforts on the investigation of BIM-based stakeholder management, especially in mega projects. Furthermore, to secure that this stakeholder methodology is too broad in its study of CSFs. Lastly, there is a necessity to carry further in-depth study on the concept of SM and what it involves. All of the success factors are significant in their individual. Therefore, the necessity to approach SM implementation from a view is fundamental to the project's success. The gap in this regard to the literature requires to be investigated in deeper detail. Expressly, there is a necessity to identify the strategies to be employed and the explicit tactics to be adopted for managing stakeholders for successful implementation of mega projects.

\section{REFERENCES}

A. Smith \& B. Wilkins (1996). Team relationship and related critical factors in the successful procurement of health care facilities. Journal of Construction Procurement, Vol. 2, no. 1, pp. 30-40. 
A. Songer \& K. Molenaar (1997). Project characteristics for successful public-sector designbuild. Journal of Construction Engineering and Management, Vol. 123, no. 1, pp. 34-40.

Aaltonen (2010). Stakeholder management in international projects ( $\mathrm{PhD}$ thesis). Aalto University, Espoo, Finland.

Adrem, A., Schneiderbauer, D., Meyer, E. \& Majdalani F. (2006). Managing airports construction projects, [Accessed 4 Augutst 2010] Available at: www.Boozallen.com.

Al-Mashari, M., Al-Mudimigh, A. \& Zairi, M. (2003). Enterprise resource planning: a taxonomy of critical factors. European Journal of Operational Research, Vol. 146, pp. 352-64.

Al-Mudimigh, A., Zairi, M. \& Al-Mashari, M. (2001). ERP software implementation: an integrative framework. European Journal of Information Systems, Vol. 10, p. 216.

Anderson, S., Vahdat, A., Dao, B., Kermanshachi, S., Shane, J. \& Hare, E. (2016). Measuring project complexity and its impact. Austin, TX: Construction Industry Institute. https://www. construction- institute.org/resources/knowledgebase/knowledge-areas/measuring-projectcomplexityandits-impact/topics/rt-305

Ayuso, S., Rodriguez, M. A. \& Ricart, J. E. (2006). Responsible competitiveness at the micro level of the firm: Using stakeholder dialogue as a source for new ideas: a dynamic capability underlying sustainable innovation. Corporate Governance, 6(4), 475-490.

Xia, B. \& Chan, A. P. C. (2010). Key competences of design-build clients in China. Journal of Facilities Management, Vol. 8, no. 2, pp. 114-129.

Bajwa, D. S., Garcia, J. E. \& Mooney, T. (2004). An integrative framework for the assimilation of enterprise resource planning systems: phases, antecedents, and outcomes. Journal of Computer Information Systems. Vol. 44, pp. 81-90.

Bourne, L. \& Walker, D. H. T. (2005). Visualizing and mapping stake-holder influence. Management Decision, 43(5), 649-660.

Brooke, K. \& Litwin, G. (1997). Mobilizing the partnering process. Journal of Management in Engineering, 13(4), pp. 42-48.

Chen, I. J. (2001) Planning for ERP systems: analysis and future trend. Business Process Management Journal, Vol. 7, p. 374.

Cleland, D. I. \& Ireland, R. L. (2007). Project Management: Strategic Design and Implementation, New York, McGraw-Hill.

Cleland, D. I. (1986). Project stakeholder management. Project Management Journal, 17(4), 3639.

Cleland, D. I. (1995). Leadership and the project management body of knowledge. International Journal of Project Management. 13(2), 82-88.

Cleland, D. I. (1998). Stakeholder management. In: Pinto J. (Ed.), Project Management Handbook, San Francisco, Jossy-Bass, Project Management Institute, 55-72.

Cliffe, S. (1999) ERP implementation. Harvard Business Review, Vol. 77, p. 16.

Cooper, R., Aouad, G., Lee, A., Wu, S., Fleming, A. \& Kagioglou, M. (2005). Process Management in Design and Construction, Blackwell Publishing.

Cova B. \& Salle, R. (2005). Six key points to merge project marketing into project management. International Journal of Project Management, 23(5), 354-359.

Čulo, K. \& Skendrović, V. (2010) Communication management is critical for project success. Informatologia, 43 (3), pp. 228-235. 
Lam, E. W. M. \& Chan, A. P. C., Chan, D. W. M. (2004). Benchmarking design-build procurement systems in construction. Benchmarking: An International Journal, Vol. 11, No. 3, pp. 287302.

Freeman, R. E. (1984). Strategic Management: A Stakeholder Approach, Pitman, Boston.

Freeman, R. E., Harrison, J. S. \& Wicks, A.C. (2007) Managing for Stakeholders -Survival, Reputation, and Success. Louis Stern Memorial Fund, US.

Gabriel, E. (2015). The human factor effect on projects'success (A Thesis Submitted to The Faculty of Graduate Studies in Partial Fulfilment of The Requirements For The Degree of Doctor Of Philosophy). Department of Civil Engineering, Calgary, Alberta.

Grilo, L., Melhado, S., Silva, S., Edward, P. \& Hardcastle, C. (2007). International Building Design Management and Project Performance; Case Study in Sao Paulo, Brazil. Architectural Engineering and Design Management, Vol. 3, pp.5-16.

Gupta, A. (2000), Enterprise resource planning: the emerging organizational value systems. Industrial Management \& Data Systems, Vol. 100, pp. 114-8.

Holland, C. \& Light, B. (1999). A critical success factors model for ERP implementation. IEEE Software, Vol. 16, p. 30.

Hong, K. K. \& Kim, Y. G. (2002). The critical success factors for ERP implementation: an organizational fit perspective. Information \& Management, Vol. 40, p. 25.

Hussain, T. (2015). A Model for Project Governance in Delivery of Oil and Gas Projects in Alberta (A Thesis Submitted to The Faculty of Graduate Studies in Partial Fulfilment of the Requirements for The Degree of Doctor 0f Philosophy). Department of Civil Engineering, Calgary, Alberta.

Jefferies, M., Gameson, R. \& Rowlinson, S. (2002). Critical success factors of the BOOT procurement system: reflections from the Stadium Australia case study. Engineering, Construction and Architectural Management, 9(4), pp. 352-361.

Jepsen, A. L., \& Eskerod, P. (2009) Stakeholder analysis in projects: Challenges in using current guidelines in the real world. International Journal of Project Management, 27(4), pp. 335343.

Jergeas, G. F., Eng. P., Williamson, E., Skulmoski, G. J. \& Thomas, J. L. (2000) Stakeholder management on construction projects. 2000 AACE International Transaction, 12.1-12.6.

Jha, K. N. \& Iyer, K. C. (2006). Critical factors affecting quality performance in construction projects. Total Quality Managemen, 17(9):1155-1170.

Kalling, T. (2003). ERP systems and the strategic management processes that lead to competitive advantage. Information Resources Management Journal, Vol. 16, p. 46.

Karlson, J. T. (2002). Project stakeholder management, Engineering Management Journal, 14 (4), pp. 19-24.

Kraemmergaard, P. \& Rose, J. (2002). Managerial competences for ERP journeys. Information Systems Frontiers, Vol. 4, p. 199.

Li, Y., Lu, Y. \& Peng, Y. (2011). Hierarchical structuring success factors of project stakeholder management in the construction organization. African Journal of Business Management, 5(22), pp. 9705-9713.

Liu, H., Jazayeri, E. \& Dadi, G. B. (2017). Establishing the influence of owner practices on construction safety in an operational excellence model. Journal of Construction Engineering and Management, 143(6), 04017005. DOI: 10.1061/(ASCE)CO.1943-7862.0001292. 
Mandal, P. \& Gunasekaran, A. (2003). Issues in implementing ERP: a case study. European Journal of Operational Research, Vol. 146, pp. 274-83.

McElroy, B. \& Mills, C. (2003). Managing Stakeholders. In: Turner, R.J. (Ed.). People in Project Management, Aldershot, Gower, 99-118.

Miller, R. \& Lessard, D. (2001). Understanding and managing risks in large engineering projects. International Journal of Project Management, 19(8), 437-443.

Mitchell, R. K., Agle, B. R. \& Wood, D. J. (1997). Toward a theory of stakeholder identification and salience: Defining the principle of who and what really counts. Academy of Management Review, 22(4), 853-886.

Moodley, K., Smith, N. \& Preece, C.N. (2008). Stakeholder matrix for ethical relationships in the construction industry. Construction Management and Economics, 26(6), 625-632.

Motwani, J., Mirchandani, D., Madan, M. \& Gunasekaran, A. (2002). Successful implementation of ERP projects: evidence from two case studies. International Journal of Production Economics, Vol. 75, p. 83.

Nguyen, N. D., Ogunlana, S. O. \& Lan, Đ. T. X. (2004) A study on project success factors in large construction projects in Vietnam. Engineering, Construction and Architectural Management, Vol. 11, no. 6, pp. 404-413.

Nah, F. F. H., Lau, J. L. S. \& Kuang, J. (2001), Critical factors for successful implementation of enterprise systems. Business Process Management Journal, Vol. 7, p. 285.

Nguyen, N. H., Skitmore, M. \& Wong, J. K. W. (2009). Stakeholder impact analysis of infrastructure project management in developing countries: a study of perception of project managers in state-owned engineering firms in Vietnam. Construction Management and Economics, 27(11), pp. 1129-1140.

Olander S. \& Landin, A. (2005). Evaluation of stakeholder influence in the implementation of construction projects. International Journal of Project Management, 23(4), 321-328.

Olander, S. (2006). External stakeholder management. (PhD thesis). Lund University, the UK.

Olander, S. (2007). Stakeholder impact analysis in construction project management. Construction Management and Economics, 25(3), pp. 277-287.

Olander, S. \& Landin, A. (2008). A comparative study of factors affecting the external stakeholder management process. Construction Management and Economics, 26(6), pp. 553-561.

Pinto, J. K. \& D. Slevin, B. (2009). Trust in Projects: An empirical assessment of owner/contractor relationships. International Journal of Project Management, 27(6), pp. 638-648.

PMBOK, PMI (Project Management Institute) (2018). A Guide to the Project Management Body of Knowledge, Fourth version, Newtown Square, Pa.

Pocock, J. B., Hyun, C.T., Liu, L.Y. \& Kim, M. K. (1997). Relationship between project interaction and performance indicators. Journal of Construction Engineering and Management, Vol. 122(2), pp.165-176.

Podnar, K. \& Jancic, Z. (2006) Towards a categorization of stake-holder groups: An empirical verification of a three-level model. Journal of Marketing Communications, 12(4), 297-308. pp. 167-175.

Ribbers, P. M. A. \& Schoo, K. C. (2002) Program management and complexity of ERP implementations. Engineering Management Journal, Vol. 14, p. 45.

Robey, D., Ross, J. W. \& Boudreau, M. C. (2002). Learning to implement enterprise systems: an exploratory study of the dialectics of change. Journal of Management Information Systems, 
Vol. 19, p. 17.

Hammad, S (2013). Investigating the Stakeholder Management in Construction Projects in the Gaza Strip, P 7.

Sarker, S. \& Lee, A. S. (2003). Using a case study to test the role of three key social enablers in ERP implementation. Information \& Management, Vol. 40, p. 813.

Scott, J. E. \& Vessey, I. (2000) Implementing enterprise resource planning systems: the role of learning from failure. Information Systems Frontiers, Vol. 2, p. 213.

Shanks, G. \& Parr, A. (2000). A model of ERP project implementation. Journal of Information Technology, Vol. 15, pp. 289-303.

Silverman, D. (2000). Doing Qualitative Research: A Practical Handbook. Sage, Thousand Oaks, CA.

Siriginidi, S. R. (2000b). Enterprise resource planning in reengineering business. Business Process Management Journal, Vol. 6, p. 376.

Skok, W. \& Legge, M. (2002). Evaluating enterprise resource planning (ERP) systems using an interpretive approach. Knowledge and Process Management, Vol. 9, p. 72.

Soh, C., Kien, S. S. \& Tay-Yap, J. (2000). Cultural fits and misfits: is ERP a universal solution? Association for Computing Machinery, Communications of the ACM, Vol. 43, p. 47.

Somers, T. M. \& Nelson, K. G. (2004) A taxonomy of players and activities across the ERP project life cycle. Information \& Management, Vol. 41, pp. 257-78.

Trimmer, K. J., Pumphrey, L. D. \& Wiggins, C. (2002). ERP implementation in rural health care. Journal of Management in Medicine, Vol. 16, p. 113.

Wahab, H. (2011). Design process and stakeholder management in airport construction. (Dissertation submitted in partial fulfillment of MSc Project Management), Faculty of Business, The British University in Dubai.

Walker, D. H. T., Bourne, L. M. \& Shelley, A. (2008). Influence, stakeholder mapping and visualization. Construction Management \& Economics, 26(6), pp. 645-658.

Weshah, N., El-Ghandour, W., Cowe Falls, L. \& Jergeas, G. (2014a). A New Approach for Evaluating and Analyzing the Impact of Interface Management (IM) on Project Performance during Engineering / Design Phase using Monte Carlo Simulation. In Proceedings of the Canadian Society for Civil Engineering Conference Halifax, Nova Scotia, Canada, May 28th -31st, 2014. (pp. GEN-128-1-10).

Wheeler, D. \& Sillanpaa, M. (1997). The stakeholder corporation: A blueprint for maximizing stakeholder value. London: Pitman Publishing. (C) University of Pretoria 128.

Wong, K. Y. \& Aspinwall, E. (2005). An empirical study of the important factors for knowledgemanagement adoption in the SME sector. Journal of Knowledge Management, 9(3): 64-82. DOI: $10.1108 / 13673270510602773$.

Xu, H., Nord, J. H., Brown, N. \& Nord, G. D. (2002). Data quality issues in implementing an ERP. Industrial Management \& Data Systems, Vol. 102, p. 47.

Yang, J., Shen, Q. P. \& Ho, M. F. (2009a). An overview of previous studies in stakeholder management \& its implications for construction industry. Journal of Facilities Management, 7(2), pp. 159-175.

Yang, J., Shen, Q. P., Ho, M. F., Drew, S. D. \& Chan, A. P. C. (2009b). Exploring critical success factors for stakeholder management in construction projects. Journal of Civil Engineering and Management, 15(4), pp. 337-348. 
Yu, T. W., Shen, Q. P., Kelly, J. \& Hunter, K. (2007). An empirical study of the variables affecting construction project briefing/architectural programming. International Journal of Project Management, 25(2), pp. 198-212.

Yusuf, Y., Gunasekaran, A. \& Abthorpe, M. S. (2004) "Enterprise information systems project implementation: a case study of ERP in Rolls-Royce. International Journal of Production Economics, Vol. 87, pp. 251-66. 